\title{
Bundling as strategy of tourist attraction based on natural and cultural tourism in the ex- Surakarta residency
}

\author{
Giyah Yuliari $^{1 *}$, Bambang Riyadi ${ }^{2}$ \\ FEB UNTAG, Semarang 50233, Indonesia ${ }^{1 *, 2}$ \\ giyah-yuliari@untagsmg.ac.id ${ }^{1^{*}}$,bambang-riyadi@untagsmg.ac.id ${ }^{2}$
}

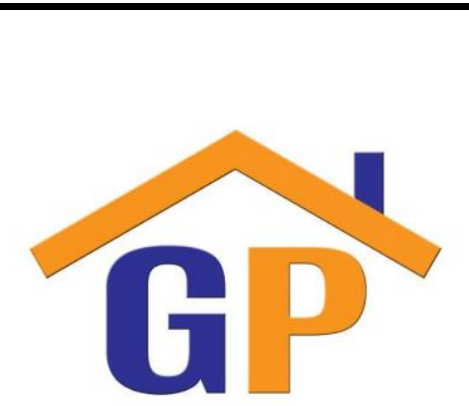

\section{Article History}

Received on 28 October 2019

$1^{\text {st }}$ Revision on 28 November 2019

$2^{\text {nd }}$ Revision on 8 December 2019

$3^{\text {rd }}$ Revision on 12 December 2019

Accepted on 15 December 2019

\begin{abstract}
Purpose: Indonesia has many tourist attractions, but not all places are well known, which makes them have no visitors. The objectives of this study are to find out how the condition of attractions in each district/ city in the Surakarta Residency and how to increase tourist visits to tourist attractions.
\end{abstract}

Research methodology: The research design is qualitative research. Data are presented in descriptive form, with in-depth and flexible analysis. Sampling by purposeful sampling, the sample chosen depends on the research objectives without regard to the ability of the generalist. The method used is implementing a bundling marketing strategy, which issues product bundling and price bundling in the form of several travel packages.

Results: There are two tourist attractions that are already developing and which are still in the form of potential. Travel agents can offer tourist attractions that have developed to tourists by bundling through tour packages. Tourist attractions that are still potential but attractive can be offered as well. So that all tourist attractions will get tourist visits.

Limitation: This research was conducted at the Ex-Residency of Surakarta, in Central Java, Indonesia. There are many types of tourist destinations, such as cultural, natural, educational, religious, sport, museum, shopping and culinary heritage tours. So that the bundling is only valid for the area.

Contribution: Application of bundling is one way to determine the selling price of a product in this case a tourism product, so that tourism products in the form of tour packages can be sold at attractive prices, which are expected to increase tourist visits.

Keywords: Bundling strategy, Tourist attraction, Tourist collaboration, Spirit of gotong royong, Developing tourism

How to cite: Yuliari, Giyah., and Riyadi, Bambang. (2019). Bundling as strategy of tourist attraction based on natural and cultural tourism in the Ex-Surakarta Residency. Journal of Sustainable Tourism and Entrepreneurship, 1(1), 1-12.

\section{Introduction}

Indonesia has many tourist destination that is well known for its uniqueness. Several well-known tourist attractions include in Yogyakarta, Bali, Lombok Island, Raja Ampat, Lake Sentani, Bunaken Marine Park, Tana Toraja, and Borobudor Temple. The tourist attraction is a destination that has been managed and developed by local governments with several standards, so they can become an icon of Indonesian tourist attraction at the world level. Tourists get the convenience of visiting Indonesia 
because the facilities such as information, transportation, accommodation and communication networks comply tourist needs. In some part, there are still many tourist attractions, which are unique but not yet known and developed.

The existence of regional autonomy launched by the Indonesian government, gives freedom to develop their regions, including developing their tourist attractions. The development of tourist attractions carried out by each region has a positive impact on the surrounding community. Tourists who visit tourist destinations will admire the uniqueness of tourist attractions, besides that they also need tourist equipment such as accommodation, transportation, tour guides, communication networks and souvenirs as a memento of a visit to a tourist destination. The equipment can be provided by the local community, of course it must be with a direction so that the equipment provided is according to standards and meets the needs of tourists. More and more tourists visit a tourist destination, the surrounding community will get various opportunities such as transportation service providers, accommodation, tour guides, culinary and making souvenirs typical of tourist destination areas. Job opportunities are open to the local community. People do not need to look for work outside the region or become Indonesian Workers or Women Workers in other countries. The efforts carried out by the community are expected to be able to encourage an increase in regional own-source revenue, (UU RI no 22, 1999), which in turn can improve people's welfare. This is what the local government hopes for.

Tourist visits will determine the development of the area. Efforts so that tourists want to visit a tourist destination must be done by the government and the community, through the Sapta Pesona program, which consists of seven elements namely safe, orderly, clean, cool, beautiful, welcoming and memorable. The Sapta Pesona program has not been fully implemented by the community. This is reflected by the small number of tourists visiting Indonesia, especially visits to tourist attractions located in the area. Indonesia, which has diverse natural resources as a tourist destination and cheaper living costs than Singapore, has not yet become a world tourist destination. Singapore's neighboring country has limited natural resources, the number of tourist visits is far more than in Indonesia. In 2018 the number of visitors to Singapore reached 18,506,600 tourists (Singapore Department of Statistics, 2019), visitors to Indonesia 15,810,305 tourists (Badan Pusat Statistik, 2019) . This is a very ironic problem, a solution must be immediately sought, so that Indonesia can utilize its natural wealth as a world-class tourist destination.

In this study, the object of research is a tourist attraction located in the Ex Surakarta Residence, Central Java Province, which includes Boyolali Regency, Klaten Regency, Solo City, Sukoharjo Regency, Wonogiri Regency, Karanganyar Regency, and Sragen Regency. This area has attractions both in the form of Nature Tourism Parks and Cultural Heritage Tourism Parks. Based on observations that have been made, there are findings that each district has a superior tourist attraction that is worthy of being offered to tourists as a tourist destination. City and Regency, in the Ex Surakarta Residence has a growing tourist attraction, more than 5 types of tourist attractions that are worth visiting as tourist destinations. The area still has the potential of many tourist attractions such as agro attractions, educational tourism and religious tourism.

The research objectives are to find out:

(a). the condition of tourist attractions in each regency / city in the Ex Surakarta Residence

(b). ways to encourage tourists to visit tourist attractions.

Based on the description above the issues raised are:

(i). What is the condition of tourist attraction in each district / city in the Ex Surakarta Residence?

(ii). How to increase tourists to visit tourist attractions ? 


\section{Literature review and hypotheses development}

\subsection{Bundling in Price and Product}

Tourist visits in areas that have tourist attractions, are very important both for the development of the region and the tourist attraction itself. Tourists visiting an area will need lodging, culinary, transportation, travel agents, tourist attractions both natural and regional arts and souvenirs (Rai Utama, 2017). The community will get the opportunity to provide for tourists. More and more tourists visiting tourist attractions, will provide a lot of business opportunities for people in the area of tourist attraction. It is hoped that business opportunities can reduce unemployment, ultimately it can improve people's welfare. The research location in the Ex-Surakarta Residence, is an area rich in cultural heritage, nature reserves, museums and natural beauty that can be offered to local and foreign tourists. The uniqueness of the tourist attraction in the Ex Surakarta Residency, has not been fully exposed widely. Based on preliminary identification, it is known that the number of tourist attractions in each region is more than 5 kinds which include attractions of water, nature, museums, cultural heritage, sports, culinary, religious, and can still be developed into several types of tourism. There must be a strategy in developing tourist attractions. Strategies that guarantee the sustainability of tourist attractions must be taken into consideration in planning tourist attractions. To solve the problems in this study, bundling strategy is one of the ways that can be used to increase tourist visits (Adams \& Yellen, 2014).

The existence of bundling makes it easy for consumers to purchase a product or service. In this research the focus is on bundling strategies which include price bundling and product bundling. The difference is price bundling as a determinant of prices and promotional tools, while product bundling is even broader, namely the existence of added value. Price bundling can change in a short time while product bundling requires a longer time if it will be changed, because it relates to the physical product and design (Tellis, 2002).

\subsection{Determination of bundling prices}

Tourist attractions that have been developed and are widely known can be offered in a package with a tourist attraction that has the potential of attraction but has not yet been developed. Through bundling, it is hoped that the potential for undeveloped tourist attraction will be known. Tourists can transparently calculate how much money must be incurred and what tourist attractions will be obtained. Bundling provides information on the number of tourist attractions and the amount of costs that must be incurred to get to the tourist attraction. Through the website, prospective tourists can arrange their trips and it will be more interesting because tourists can choose and compare the desired packages according to their budget (Ghorbani, Danaei, Zargar, \& Hematian, 2019). The existence of a tourist attraction bundling, it is expected that every tourist attraction, both already and undeveloped, will get tourist visits. Through bundling tour packages can be arranged so that tourists will be able to determine the package that suits their needs. There are 2 dimensions of bundling namely the focus of bundling on the product or price and the form of bundling that is pure or mixed (Xu, Kin, Wong, \& Tan, 2016).

Price bundling is the sale of two or more separate products as a package, for example tourists are offered land and hotel packages. This offer includes two separate products, on one side of the road trip is part of the transportation activities unit, on the other hand the hotel is an activity offering lodging services, tourists will be more facilitated to take a tour, besides that the costs incurred for travel are cheaper due to discounts buy two separate products, without product integration (Gökgür \& Karabat1, 2019). Product bundling is the integration and sale of two or more separate products at various prices, for example guided tours. Tourists can visit the tourist attraction with a tour guide. Without a tour guide, tourists can actually enjoy the tourist attraction visited, but even so it will be different if 
accompanied by a tour guide. Tourists will be more satisfied because the tour guide can provide an explanation of the tourist attractions that tourists enjoy (Xu et al., 2016).

Pure bundling is a strategy where the company only sells bundles and not (all) products separately. For example the sale of souvenirs and packing services even though there are two different services but the price is fixed, there is no additional packing fee, so if you buy souvenirs you will get free packing because it includes the bundled price (Hui, Yoo, Choudhary, \& Yan, 2012).

Mixed Bundling is a strategy in which a company sells both and (all) products separately. For example: Offering tour packages in two different tourist attractions, culinary tourism attractions and natural tourist attractions. Tourists will get the opportunity to visit two different tourist attractions at a lower cost than without a package. However, tourist attraction packages that are not integrated with regular prices are also sold, so tourists can visit two tourist attractions without the package of each tourist attraction subject to regular fees (Tellis, 2002).

Pricing through bundling is better than market-based pricing and production which is more complicated because there are several goals to set low prices, namely low prices are set so that products sell a lot because the cost of production will ultimately be profitable, prices are determined to maximize profits, set product prices higher quality, maximizing productivity to increase market share and set prices as same as competitors do (Rafiei, Rabbani, Razmi, \& Jolai, 2013).

\section{Research methodology}

This research uses qualitative research as its approach. The data was presented in a descriptive form, with in-depth and flexible analysis because it can change according to the situation in the field and research objectives. However, researchers would use guidelines to follow, but not standard rules (Sugiyono, 2009). The research that has been done can change as needed, the field situation and new hypotheses that arise during the course of the research. Sampling by purposeful sampling, the sample chosen depends on the research objectives with no regard to the ability of the generalist. Research locations was in the former Surakarta Residency area include Klaten, Boyolali, Wonogiri, Sukoharjo, Sragen, Surakarta City and Karanganyar. The location has the attraction of nature reserves and cultural reserves, for example: Sangiran Museum, Sukuh Temple, Cetho Temple and Kethek Temple. Through careful mapping, product bundling strategies and the price of a visit to the right tourist destination can be determined, and finally an efficient tour package can be made.

Data collection methods depend on the data needed. This research requires primary data and secondary data. Primary data, data obtained from informants, people who know deeply about the problem to be studied, the data collection method used is observation, which is a way of collecting data by direct observation to the research object, open structured or unstructured interviews. Secondary data, data derived from the study of several documents, literature and related notes, documentation in the form of photos of video footage of the object of research.

Determination of informants was done purposively, one of which is to choose informants who are experienced and have knowledge about tourist attractions that come from nature and cultural preservation officers. Research instruments or research tools are researchers themselves so researchers must be "validated". Validation of researchers, including; understanding qualitative research methods, mastery of insight into the field under study, the readiness of researchers to enter the object of research-both academically and logically (Sugiyono, 2009). Data analysis was carried out in a descriptive qualitative and interpretative manner. Furthermore, the data process by stages, reducing data, how to choose and convert the data obtained. Data will be presented by compiling it, and sorted into one integrated database. Conclude by reviewing as necessary by test the fact. The results are interpreted and presented in narrative form (Miles, M.B \& Huberman, 1984).

The Researchers need to know the field conditions as the actual research object to assist in planning data collection, by visiting research sites which include Boyolali Regency, Klaten Regency, 
Solo City, Sukoharjo Regency, Wonogiri Regency, Karanganyar Regency, and Sragen Regency. The actors, basically on the data obtained, the next step is to determine the prospective participants according to the characteristics of the study, develope interview protocols, including: (a) introduction; (b) opening statement; (c) key questions; and (d) probing. The process, basically on the preparations in the first to third sections, an overall data collection strategy was developed. This strategy includes all data collection planning starting from the conditions, approach strategies and how data collection is done.

\section{RESULTS AND DISCUSSIONS}

\subsection{Type of Tourist Attraction in Ex-Surakarta Residency}

The study was conducted at the former residency of Surakarta which included Boyalali, Karanganyar. Travel attractions that can be identified as follows:

Table 1. Boyolali Tourist Destination

\begin{tabular}{l|l|l}
\hline No. & \multicolumn{1}{|c}{ Name } & \multicolumn{1}{c}{ Type } \\
\hline 1. & Umbul Pengging & Water tourism \\
\hline 2. & Taman wisata Tlatar & Water tourism \\
\hline 3. & Candi Lawang dan Candi Sari & Religious tourism \\
\hline 4. & Puro Bahawanatata & Religious tourism \\
\hline 5. & Kampung Lele & Educational tourism \\
\hline 6. & Kerajinan Tembaga & Educational tourism \\
\hline 7. & Trekking Gunung Merapi & Natural tourism \\
\hline 8. & New Selo & Natural tourism \\
\hline 9. & Bukit Gancik & Natural tourism \\
\hline 10. & Alam Sutera & Natural tourism \\
\hline 11. & Oemah Bambu Merapi & Natural tourism \\
\hline 12. & Watu Barek & Natural tourism \\
\hline 13. & Jembatan Gantung & Natural tourism \\
\hline 14. & Tikungan Cinta & Natural tourism \\
\hline 15. & Bukit Kinasih & Natural tourism \\
\hline 16. & Musium R Hamong Wardoyo & Museum \\
\hline Source: Dinas Olah Raga Dan Pariwisata 2019
\end{tabular}

Table 1 shows that Boyolali Regency has a tourist attraction dominated by natural tourist attractions, because the Boyolali area is surrounded by mountains including Mount Merapi and Mount Merbabu. Other tourist attractions such as religious tourism, education and museum attractions are worthy of being made tourist destinations. Many potentials have not yet been developed that require attention and hard work. One tourist attraction that can be used as a tourist attraction is gastronomic tourism. The data collection on typical traditional gastronomic are still in process. Sometimes tourists come because of the gastronomic tourist attraction (Berbel-pineda, Palacios-florencio, \& Ramírezhurtado, 2019).

Karanganyar Regency has its own uniqueness, diverse tourist attractions and innovative management. The following are the tourist attractions that have developed and new innovative tourist attractions. 
Tabel 2. Karanganyar Tourist Destination

\begin{tabular}{l|l|l}
\hline No. & \multicolumn{1}{|c|}{ Name } & \multicolumn{1}{c}{ Type } \\
\hline 1 & Waterfall & Water tourism \\
\hline 3 & Pringgodani & Water tourism \\
\hline 4 & Telaga Madirda & Water tourism \\
\hline 5 & Sapta Tirta Pablengan & Water tourism \\
\hline 7 & Teh Kemuning & Educational tourism \\
\hline 8 & Candi Cetho & Cultural Heritage Tourism \\
\hline 9 & Candi Sukuh & Cultural Heritage Tourism \\
\hline 10 & Astana Giribangun & Religious tourism \\
\hline 11 & Kampung Halloween & Natural tourism \\
\hline 12 & Lawu Park & Natural tourism \\
\hline 13 & The Lawu Peak & Sport tourism \\
\hline 14 & Bukit Paralayang & Sport tourism \\
\hline 15 & Waduk Lalung & Sport tourism \\
\hline 16 & Musium Tjolomadu & Museum tourism \\
\hline
\end{tabular}

Source: Dinas Pemuda Dan Olah Raga 2019

Karanganyar has a variety of tourist attractions. Table 2 informs that tourist attractions can be grouped into water tourism attractions, educational tours, cultural heritage, nature tourism and sports tourism. Since the government gave village funds, each village has built its village with the spirit of gotong royong. Gotong Royong is an activity carried out together and is voluntarily so that the activities carried out can run smoothly, easily and lightly. The easiest village development is to build a tourist attraction. Based on field observations, each village has a similar type of tourist attraction. There is probably no unique tourist attraction that can be exposed. Tourists will not visit, there is nothing different from the tourist attractions that have been found (Zhong, Sun, \& Law, 2019).

That problem can be solved by the collaboration between villages or districts that have the same tourist attraction, which is based on the spirit of gotong royong. Collaboration is cooperation that is accompanied by agreement on something (Wong, Mistilis, \& Dwyer, 2011). In this case the tourist attraction that will be exposed to become an area's tourist attraction icon (Fabeiro, Maga, \& Svenson, 2013).

Sragen Regency is a regency that has a tourist attraction that the museum has already recognized by the world. Because of the many fossils, this place was confirmed by UNESCO as a world cultural heritage.

Tabel 3. Sragen Tourist Destination

\begin{tabular}{c|l|l}
\hline No. & \multicolumn{1}{|c|}{ Name } & \multicolumn{1}{c}{ Type } \\
\hline 1 & Situs Manusia Purba Sangiran & Museum tourism \\
\hline 2 & Klaster Krikilan & Museum tourism \\
\hline 3 & Klaster Bukuran & Museum tourism \\
\hline 4 & Klaster Ngebug & Museum tourism \\
\hline 5 & Musium Situs Manyarejo & Museum tourism \\
\hline 6 & Gunung Kemukus & Religious tourism \\
\hline 7 & Kliwonan Desa Wisata batik & Educational tourism \\
\hline Source: Dinas Pemuda Olahraga dan Pariwisata 2019 &
\end{tabular}


In contrast to tourism in other regencies, Sragen has a fascinating tourist attraction with prehistoric museums. Visitors will gain knowledge about Ancient humans. Detailed show room arrangement is easily understood by visitors. Another attraction is Mount Kemukus, which is very famous and visited by many people because of the belief that it will bring fortune. But lately it has become an unfit place for religious tourism. The Kliwonan Area is a place for making, selling as well as batik training, and its quiet area can also be used to explore the villages.

The main tourist attraction of Klaten Regency is the tourist attraction of Cultural Heritage, relics in the form of temples which are very interesting among others as shown in the following table:

Tabel 4. Klaten Tourist Destination

\begin{tabular}{c|l|l}
\hline No. & \multicolumn{1}{|c|}{ Name } & \multicolumn{1}{c}{ Type } \\
\hline 1. & Candi Prambanan & Cultural Heritage Tourism \\
\hline 2 & Candi Plaosan & Cultural Heritage Tourism \\
\hline 3 & Candi Sewu & Cultural Heritage Tourism \\
\hline 4 & Umbul Ponggok & Water Tourism \\
\hline 5 & Rowo Jombor & Culinary Tourism \\
\hline 6 & Museum Gula & Museum \\
\hline 7 & Kerajinan Lurik & Educational tourism \\
\hline 8 & Peternakan Sapi & Educational tourism \\
\hline 9 & Kerajinan Batik & Educational tourism \\
\hline Source $:$ Dinas Pariwisata Budaya Pemuda Dan Olahraga 2109
\end{tabular}

Table 4 shows that in addition to cultural heritage tours, there is also a well-known educational tour, namely ATBM lurik educational tour (Non-Machine Weaving Equipment), which in other words everything is done manually. Klaten Lurik is very famous, this tour will provide an experience for tourists how to make lurik weaving. Batik crafts in the village of Jarum, provide opportunities for tourists to make batik both batik and batik on wood. Sukoharjo Regency has a diverse tourist attraction. Nature tourism occupies the most places, besides that Cultural Heritage Tourism and Educational Tourism. The following is presented in table 5. Kab. Sukoharjo as follows.

Tabel 5. Sukoharjo Tourist Destination

\begin{tabular}{c|l|l}
\hline No. & \multicolumn{1}{|c|}{ Name } & \multicolumn{1}{c}{ Type } \\
\hline 1. & Curug Krajan & Natural tourism \\
\hline 2 & Gunung Sepikul & Natural tourism \\
\hline 3 & Umbul Pecinan Batu Seribu & Natural tourism \\
\hline 4 & Telaga Biru & Natural tourism \\
\hline 5 & Telaga Claket & Natural tourism \\
\hline 6 & Sendang Pinilih & Natural tourism \\
\hline 7 & Pesanggrahan Langenharjo & Cultural Heritage Tourism \\
\hline 8 & The Heritage Palace - Pabrik Gula & Cultural Heritage Tourism \\
\hline 9 & Gembongan & \\
\hline 10 & Pakam Mbalakan & Cultural Heritage Tourism \\
\hline 11 & Pengrajinan Wayang dan gamelan & Educational tourism \\
\hline 12 & Kampung jamu Nguter & Educational tourism \\
\hline 13 & Pengrajin Gitar & Educational tourism \\
\hline 14 & Pengrajin kopiah & Educational tourism \\
\hline
\end{tabular}

Source : Kebudayaan Dan Pariwisata 2019 
The tourism attraction of Sukoharjo Regency is not only natural and cultural tourism, educational tourism and water tourism can also be considered as tourist destinations. Educational tours on wayang and Gamelan crafts are very interesting because they don't exist anywhere else. Likewise, guitar craftsmen and skullcap, the products produced are very specific. What should be done to find a solution so that tourists know and want to come to the tourist attraction. The manager of tourist attraction must be smart and have product knowledge, which in this case tourism products. There are various ways to introduce tourist destinations. The manager of tourist attraction must be smart and have product knowledge, in this case tourism products. There are various ways to introduce tourist destinations. The method of one bundling will set a lower price to enjoy two or more types of tourist attractions. The tourist attraction is packaged in informative tour packages that will encourage tourists to visit the tourist attraction (Xu et al., 2016).

The city of Surakarta location is close to Sukoharjo Regency, which is the only city of the former residency of Surakarta. Surakarta has a very innovative tourist attraction, supported by many historical heritages and cultural heritage, making Surakarta counted as a tourist destination. Tourism Attractions in the City of Surakarta can be followed in the following table

Tabel 6. Surakarta Tourist Destination

\begin{tabular}{c|l|l}
\hline No. & \multicolumn{1}{|c|}{ Name } & \multicolumn{1}{c}{ Type } \\
\hline 1 & Keraton Surakarta Hadiningrat & Cultural Heritage Tourism \\
\hline 2 & Taman Sriwedari & Cultural Heritage Tourism \\
\hline 3 & Pura Mangkunegaran & Cultural Heritage Tourism \\
\hline 4 & Benteng Vastenburg Fort & Cultural Heritage Tourism \\
\hline 5 & Ngarsopuro Night Market & Shopping Tour \\
\hline 6 & Galabo Wisata Kuliner Solo & Culinary Tourism \\
\hline 7 & Kampung Batik Kauman & Shopping Tour \\
\hline 8 & Kampung Batik Laweyan & Shopping Tour \\
\hline 9 & Pasar Antik Triwindu & Shopping Tour \\
\hline 10 & Pasar Klewer & Shopping Tour \\
\hline 11 & Monumen Pers Nasional & Museum \\
\hline 12 & Museum Radya Pustaka & Museum \\
\hline 13 & Kampung wisata Baluwerti & Educational tourism \\
\hline 14 & Kampung Joho & Educational tourism \\
\hline 15 & Taman Cerdas Jebres & Educational tourism \\
\hline 16 & Kampung Blangkon & Educational tourism \\
\hline
\end{tabular}

Sumber : Dinas Pariwisata Kota Surakarta 2019

The management of attractions in the city of Surakarta, which includes cultural preservation, museums, shopping and education, is not all done by the Department of Tourism. Communities are given the freedom to develop the potential that exists in their territory. For example, in the Baluwerti district there are many tourists visiting the village who are interested in the culture around them, making a package that tourists want. The package consists of learning Javanese dance, playing gamelan and cooking traditional food which is famous for liwet rice. This package is very popular with domestic and foreign tourists. The tourism office always carries out assistance, guidance, supervision and development of tourist destinations organized by the local community. Besides that, it also spreads information through brochures, the internet and travel agents (Zhang, Wei, Fu, Hua, \& Wang, 2019).

Wonogiri Regency has a diverse tourist attraction there are museums, beautiful nature and sports. In detail, the tourist attractions of the Wonogiri district will be described as follows: 
Tabel 7. Wonogiri Tourist Destination

\begin{tabular}{c|l|l}
\hline No. & \multicolumn{1}{|c}{ Name } & Type \\
\hline 1 & Museum Karst Dunia & Museum \\
\hline 2 & Museum Wayang Indonesia & Museum \\
\hline 3 & Waduk Gajah Mungkur & Natural tourism \\
\hline 4 & Goa Putri Kencono & Natural tourism \\
\hline 5 & Pantai Sembukan & Natural tourism \\
\hline 6 & Papan Luncur Gantole & Sport Tourism \\
\hline 7 & Goa Maria & Religious tourism \\
\hline 8 & Desa Wayang & Educational tourism \\
\hline 9 & Desa Sokolangit & Natural tourism \\
\hline
\end{tabular}

Source: Dinas Kepemudaan dan Olahraga Dan Pariwisata 2019

At the Karst museum, there is a diverse collection of rocks, which tourists can learn how to form a mountain. The wayang museum is very interesting because there are various collections of Indonesian puppet shows. The educational attraction of making puppets visited by many foreign tourists, to learn to make puppet crafts.

\subsection{Application of Tourist Attraction Bundling Strategy}

The former Surakarta Residency has two air sport tourism locations, namely paragliding, which is located in Wonogiri Regency and in Karanganyar Regency. This sport is still rarely found because not all regions and countries have locations that can be used as air sports. In the future this air sport will become a reference for the sustainability of tourist attractions. Preparation of air sports as a tourist attraction in the future must be prepared from now on, so that the sustainability of tourist visits is not interrupted because there are rare and challenging tourist attractions. Information and preparation and regulation on the use of air as a sporting facility must be regulated so that tourists are safe in air sports (Angelevska-najdeska \& Rakicevik, 2012).

Information about air tourism attractions can be included in bundling, so that the existence of air tourism attractions can be known to potential domestic and foreign tourists. Agents who manage tourist attractions or travel agents, can do the Bundling Strategy by making tour packages to be offered to tourists. Bundled tour packages are a bundle of products because they offer tourist destinations. The purpose of product bundling compiled by the Office that manages the tourist attractions is of course different from those made by travel agents. Tour Packages made by the Office not only seek profit, but rather lead to government goals to develop tourist destinations in the area. In this research the main objective is to make a product bundling that encourages tourists to visit tourist attractions. Based on research in the field and information from the Office that manages tourist destinations, it is known that tourist visits are inseparable from the costs incurred to enjoy tourist destinations. In making product bundles, the price or cost must be taken into account (Beladev, Rokach, \& Shapira, 2016). The application of bundling for tourist attractions in the former Surakarta Residency can be described as follows:

Tabel 8. Tourist Attraction Bundling

\begin{tabular}{l|l|l|l|l}
\hline \multicolumn{1}{c|}{ Location } & \multicolumn{3}{|c}{ Bundling } \\
\hline Boyolali & Natural tourism & Water tourism & & \\
\hline Sragen & Museum tourism & Educational tourism & & \\
\hline Sukoharjo & Educational tourism & Natural tourism & $\begin{array}{l}\text { Cultural Heritage } \\
\text { Tourism }\end{array}$ & \\
\hline
\end{tabular}




\begin{tabular}{l|l|l|l|l} 
Surakarta & $\begin{array}{l}\text { Cultural Heritage } \\
\text { Tourism }\end{array}$ & Shopping Tour & Educational tourism & Museum tourism \\
\hline Wonogiri & Museum tourism & Educational tourism & Sport tourism & Natural tourism \\
\hline Karanganyar & Water tourism & $\begin{array}{l}\text { Cultural Heritage } \\
\text { Tourism }\end{array}$ & Natural tourism & Sport tourism \\
\hline Klaten & $\begin{array}{l}\text { Cultural Heritage } \\
\text { Tourism }\end{array}$ & Water tourism & Educational tourism & Museum tourism \\
\hline
\end{tabular}

Source: Primary data, 2019

Table 8 informs tourist attraction bundling that each region has a different tourist attraction. Boyolali Regency has very many natural attractions, so the package made contains the choice of nature tourism and water tourism. This nature tourism is perfect for the milineal. They can take selfies and tracking.

Museum tourism is very famous, especially the ancient museum, The Purba Museum is located in Sragen regency, precisely in Sangiran village. Museum can be bundled with educational tours in the form of training to make batik Its location in the Kliwonan village. There is a tourist village where to learn a make batik craft. There are many home stays for tourists who want to live the life and atmosphere of the village

Sukoharjo Regency has educational tours such as making gamelan, guitar, skullcap and herbal medicine. There is a sugar museum which is a cultural heritage whose name is the Gembongan Museum. This sugar factory is not operating, the tourist attraction in the form of the beauty of the building. Bundling can be done so that one not only visits the attractions to the Sugar museum but also can see the process of making gamelan and guitar or skullcap.

The city of Surakarta has a Cultural Heritage Tourism which mainly consists of the Surakarta Hadiningrat and the Pura Mangkunegaran. The famous Batik Garment can be purchased at the Batik clothing shopping center located in the Klewer, Laweyan and Kauman markets. Educational tours in the form of historical packages can be bundled with other tours.

The Karst Museum and the wayang museum are located in The Wonogiri Regency especially in the village of Kepuh Sari, that very famous as a tourist attraction. It can be bundled with educational tourism in the form of making wayang crafts in the village of Kepuh Sari. Wonogiri Regency has a beautiful beach, called Sembukan beach. Thera are famous for paragliding and nature tourism. Beautiful beach views can already become an international tourist destination. This is a challenging tourist attraction. This attraction can be offered to tourists in the form of bundling packages with other tourist attractions.

Grojogan Sewu, a very beautiful waterfall is located in Tawangmangu. This is the natural wealth owned by Karanganyar Regency. This tour can be bundled with a sugar museum tour is called Tjolomadu museum, that is no longer in operation. Bundling is not only between sugar museum and water sports tourism. But it can also be with other tourist attractions according to the wishes of tourists or according to travel packages prepared by travel agents

Cultural Heritage tourism such as visiting Prambanan temple can be bundled with educational tourism in the form of making ATBM such as striated woven cloth (Non-Machine Weaving Equipment), water tourism, or the Sugar museum which is still operating (Gondang Winangun). The location is inside the sugar factory. Based on observations and interviews with the department of tourist destination management, the government is very serious in developing tourist attractions. This is evidenced by the many tourist attractions which a few years ago were still in the form of potential now becoming a developing and advanced tourist attraction. The tourist attraction that is owned by the government is an asset that can be used to find local revenue. Each local government can determine fees according to the target that must be achieved.This has caused retribution to enjoy 
almost the same tourist attraction, but the price is different. Pricing price bundling must be careful, because tourists with available information can choose the same tourist attraction at a cheaper price. For now the government only determines retribution rates, price bundling is carried out by travel agents, who offer tour packages to tourists. Creative and innovative strategies must not stop and must be planned in the long run (Fang, Sun, \& Gao, 2017). The development of tourist attractions must be different from tourist attractions in other areas. One example of the development of tourist attractions is the emergence of aero sport tourism which has been launched in Semarang Regency and is ready to bring tourists from foreign countries. This sport requires special locations such as valleys or mountains. Therefore not all locations can be used for aero sports tourism.

\section{Conclusion}

Tourist attractions that have developed and advanced, must be widely informed. Prospective tourists will learn tourist destinations that are in accordance with their wishes. Detailed information is needed. The more tourists come to the tourist attraction, the tourist destinations will develop and advance. Bundling Strategy is a strategy that sells two or more products into one price, which is cheaper than selling the most. Bundling strategies in tourist attractions can be grouped into nature tourism, water tourism, museum tourism, cultural heritage tourism, sports tourism, shopping tourism, religious tourism and educational tourism. All types of tours exist in all districts in the Ex-Surakarta Residency. Planning ahead must lead to something innovative. Tourist visits both from within and from foreign countries will be a determinant of the development of regional tourist attraction. The more tourists visit the area, the more attractive the tourist attractions are. It is expected that with the bundling strategy more people will visit the tourist attractions

\section{Limitation and study forward}

The results of this study can only be applied to Ex-Surakarta Regency. The results of the study can be used as an effort to develop tourist attractions in the locations. In addition, the results of the study are expected to be used as a reference for future researchers.

\section{Acknowledgement}

The authors thanks to Allah SWT. The authors would also like to thank the Directorate of Research and Community Service at the Ministry of Research, Technology and Higher Education, Directorate General of Research and Technology Strengthening, Ministry of Research, Technology and Higher Education, Rector of the University of August 17, 1945 (UNTAG) and Dean of the Faculty of Economics and Business UNTAG Semarang. Chairperson of the UNTAG Research Institute Semarang. All editors of Journal of Sustainable Tourism and Entrepreneurship (JoSTE), which have provided enthusiasm, encouragement, direction and input that is very useful for the completeness of writing this paper. All tourist attraction managers at the Ex-Surakarta Residency who have helped in providing data for the completeness of this paper. I hope this article can be an input for the development of tourist destinations. For further researchers, hopefully it can be a reference.

\section{References}

Adams, W. J., \& Yellen, J. L. (2014). Commodity bundling and the burden of monopoly. The Quarterly Journal of Economics, Vol . 90 , No . 3 ( Aug ., 1976 ), pp . 475-498, 90(3), 475-498.

Angelevska-najdeska, K., \& Rakicevik, G. (2012). Planning of sustainable tourism development, 44, 210-220. https://doi.org/10.1016/j.sbspro.2012.05.022

Badan Pusat Statistik. (2019). Data kunjungan wisatawan asing ke Indonesia. Jakarta Indonesia: BPS. Retrieved from https://www.bps.go.id/dynamictable/2018/04/05/1296/jumlah-kunjungan- 
wisatawan-mancanegara-per-bulan-ke-indonesia-menurut-pintu-masuk-2017-2019.html

Beladev, M., Rokach, L., \& Shapira, B. (2016). Knowledge-based systems recommender systems for product bundling. Knowledge-Based Systems, 111, 193-206.

https://doi.org/10.1016/j.knosys.2016.08.013

Berbel-pineda, J. M., Palacios-florencio, B., \& Ramírez-hurtado, J. M. (2019). Gastronomic experience as a factor of motivation in the tourist movements. International Journal of Gastronomy and Food Science, 18(July), 100171. https://doi.org/10.1016/j.ijgfs.2019.100171

Fabeiro, C. P., Maga, I., \& Svenson, G. (2013). Sustainable tourist management : Participation and collaboration for innovation, 100-104. https://doi.org/10.1016/j.tekhne.2013.11.002

Fang, Y., Sun, L., \& Gao, Y. (2017). Bundle-pricing decision model for multiple products bundlepricing decision model for multiple products. Procedia Computer Science, 112, 2147-2154. https://doi.org/10.1016/j.procs.2017.08.243

Ghorbani, A., Danaei, A., Zargar, S. M., \& Hematian, H. (2019). Heliyon designing of smart tourism organization ( STO ) for tourism management : A case study of tourism organizations of South Khorasan province, Iran. Heliyon, 5(November 2018), e01850. https://doi.org/10.1016/j.heliyon.2019.e01850

Gökgür, B., \& Karabat1, S. (2019). Dynamic and targeted bundle pricing of two independently valued products, 279(October 2013), 184-198. https://doi.org/10.1016/j.ejor.2019.05.022

Hui, W., Yoo, B., Choudhary, V., \& Yan, K. (2012). Sell by bundle or unit ?: Pure bundling versus mixed bundling of information goods. Decision support systems, 53(3), 517-525. https://doi.org/10.1016/j.dss.2012.02.008

Miles, M.B \& Huberman, A. M. (1984). Analisis data kualitatif. (Tjetjep Rohendi Rohidi, Ed.). Jakarta: Universitas Indonesia.

Rafiei, H., Rabbani, M., Razmi, J., \& Jolai, F. (2013). Product bundle pricing in the new millennium : A literature review, 2(3), 109-118.

Rai Utama, I. G. B. (2017). Pemasaran pariwisata. (Aditya Ari C, Ed.) (1st ed.). Yogyakarta: Penerbit Andy.

Singapore Department of Statistics. (2019). Tourism statistics on the tourism sector and hotel industry are compiled by the Singapore Tourism Board. Singapura. Retrieved from https://www.singstat.gov.sg/find-data/search-by-theme/industry/tourism/latest-data

Sugiyono. (2009). Metode penelitian kuantitatif, kualitatif dan R\&D. Bandung: Alfabet.

Tellis, G. J. (2002). Strategic bundling of products and prices : A new synthesis fbr i V lariceting, 66(January), 55-72.

UU RI no 22. (1999). Pemerintah daerah. Jakarta Indonesia. Retrieved from https://kitabhukum.files.wordpress.com/2013/11/uu-no-22-th-1999.pdf

Wong, E. P. Y., Mistilis, N., \& Dwyer, L. (2011). A model of Asean collaboration in tourism. Annals of Tourism Research, 38(3), 882-899. https://doi.org/10.1016/j.annals.2010.12.008

Xu, Y. H., Kin, I., Wong, A., \& Tan, X. S. (2016). Exploring event bundling: The strategy and its impacts. Tourism Management, 52, 455-467. https://doi.org/10.1016/j.tourman.2015.07.014

Zhang, T., Wei, W., Fu, X., Hua, N., \& Wang, Y. (2019). Exploring the roles of technology, people, and organization in building a tourism destination experience : Insights from the 2nd USA-China tourism research summit and Industry Dialogue. Journal of Destination Marketing \& Management, (November 2018), 0-1. https://doi.org/10.1016/j.jdmm.2019.03.001

Zhong, L., Sun, S., \& Law, R. (2019). Movement patterns of tourists. Tourism Management, 75(June), 318-322. https://doi.org/10.1016/j.tourman.2019.05.015 